\title{
Employability in Higher Education: Problems and Prospectives
}

\author{
M. C. Reddeppa Reddy* \\ Professor, UGC Emeritus Fellow \& Former Director, Departmet of Adult and Continuing Education, Sri Venkateswara University, \\ Tirupati, Andhra Pradesh 517502, India
}

\section{${ }^{*}$ Corresponding Author}

M. C. Reddeppa Reddy

\author{
Article History \\ Received: 14.08 .2019 \\ Accepted: 27.08 .2019 \\ Published: 04.11.2019
}

\begin{abstract}
About 3.5 million graduates, on an average, every year 22,000 graduate students are coming out from Higher Educational Institutions in India, but all of them are not getting employment. Thus, the country has more than $50 \%$ able-bodied unemployed (300 million) between the ages of 18 to 50 years and they do not have required skill sets. Recruitment companies say that many of the students, who are coming out with degrees, do not have requisite employability skills to secure employment. It is estimated that by 2025 , about 300 million educated youth will be waiting for jobs/ employment in the country. However, employers in India are facing a huge shortage of skilled manpower. Thus, there is little connection between education and employability of students. Ensuring the employability of students is an intrinsic part of good education and is a government priority. It is reflected in the performance indicators of educational institutions and it is likely to become increasingly important to prospective students in their choice of course and required budget for providing good infrastructure. Increasingly, our graduates have to compete for jobs with talented youth outside the states or even outside the country. To secure employment, the students must develop communication skills, self-confidence / high aspirations, transact the course curriculum effectively, involve in extra-curricular activities, aware of job opportunities, develop career related experience, linkages with the providers of employment, aware of selection procedure, face the interviews boldly etc., are important. The present paper entitled 'Employability in Higher Education: Problems and Prospects' discusses about the concept of employability, status of employability of students and problems faced for the employability of students. The paper also explains about the need for employability of students and pre-requisites for employability of students. Further, the prospects in the employability of students in higher educational institutions will be discussed.
\end{abstract}

Keywords: Employability, Higher Education, Students, Skill sets Work experience, Placements, Internships, Career options, Career pathways.

\section{INTRODUCTION}

In India the demand for labour, particularly for skilled and qualified, is likely to remain high and robust in the coming years. The employability of graduates has emerged as a major concern in recent years. Ironically, it is not just the uneducated and untrained that lack skills but it is also the educated that consistently lie below the required standards. About 3.5 million graduates, on an average, 22,000 graduate students every year are coming out from Higher Educational Institutions in India, but all of them are not getting employment. Thus, the country has more than 50 per cent able-bodied unemployed ( 300 million) between the ages of 18 to 50 years and they do not have required skill sets.

However, ensuring the employability of students is an intrinsic part of good education and is a government priority. It is reflected in the performance indicators of educational institutions and it is likely to become increasingly important to prospective students in their choice of course and required budget for providing good infrastructure. Increasingly, our graduates have to compete for jobs with talented youth outside the states or even outside the country. To secure employment, the students must develop communication skills, self-confidence / high aspirations, transact the course curriculum effectively, involve in extra-curricular activities, aware of job opportunities, develop career related experience, linkages with the providers of employment, aware of selection procedure, face the interviews boldly etc. are important.

Copyright @ 2019: This is an open-access article distributed under the terms of the Creative Commons Attribution license which permits unrestricted use, distribution, and reproduction in any medium for non commercial use (NonCommercial, or CC-BY-NC) provided the original author and source are credited. 
The present paper entitled 'Employability in Higher Education: Problems and Prospective' discusses about the concept of employability, status of employability of students, the need for employability of students and pre-requisites for employability of students. The paper also identifies the problems faced for the employability of students. Further, the prospective in the employability of students in higher educational institutions will be discussed.

\section{Concept of Employability}

Employability skills or generic skills are those which can be applied to most workplace situations. They are general in nature, and cover a range of 'whole of job' experiences. They are sometimes referred to as the 'soft' skills, but teachers should not take this to mean they are dispensable or easy to learn. For many students, mastering employability skills can be a challenging and confronting process, requiring intensive teacher and institute input and explicit teaching, role modeling and task planning. Employability is 'a set of achievements - skills, understandings and personal attributes - that make graduates more likely to gain employment and be successful in their chosen occupations, which benefits themselves, the workforce, the community and the economy' [1].

Employability refers to an individual's perception of his or her possibilities of getting new, equal, or better employment. It refers to a person's capability for gaining and maintaining employment [2]. For individuals, employability depends on the knowledge, skills and abilities they possess, in addition to the way they present those assets to employers. The USEM model outlines employability as four broad and inter-related components, viz., Understanding, Skilful practices (including deployment of skills), Efficacy beliefs (including students' views of themselves) and Meta-cognition (including self-awareness and a capacity to reflect on learning) [3]. Thus, the term 'employability' is part of mainstream discourse about expected outcomes for higher education. The increased stress on the employability of their graduates has challenged colleges and universities to evaluate and prioritize the fit between education and training and the workplace. Employability means that institutions and employers have supported the student knowledge, skills, attributes, reflective disposition and identity that graduates need to succeed in the workforce [3-7].

Employability skills, while categorized in many different ways, are generally divided into three skill sets: basic academic skills, higher order thinking skills and personal qualities. (i) The basic skills are necessary for getting, keeping and doing well on a job. (ii) Application of higher order thinking skills in the use of technology, instruments, tools and information systems takes these higher order skills to a new level, making the employee even more valuable. (iii) Employees with good personal skills practice good personal habits, come to work as scheduled, on time and dressed appropriately, and are agreeable to change when necessary. These are the skills, attitudes and actions that enable workers to get along with their fellow workers and supervisors and to make sound, critical decisions. Employability skills are a set of skills and behaviors that are necessary for success in every job. These skills are sometimes called soft skills, foundational skills, work-readiness skills, or job-readiness skills [8].

\section{Status of Employability of Students}

Many Indian youth are unemployed, under-employed, employed in jobs of low quality and working long hours for low wages. Many of them are engaged in dangerous work or receive only short term and or informal employment arrangements. More than 50 per cent of the employed youth are disadvantaged due to lack of workplace skills. Yet we are today suffering with an awfully low employability rates in metropolitan cities like Chennai, Delhi and Bangalore.

The then HRD Minister Rajnath Singh, on October, 2014 said that it is important to focus on skill development. But, as per the Times Higher Education Survey, not even one Indian university featured in the list of top 275 universities in the world. Quoting Wheel box on Employability, the minister said 'only 34 per cent of our graduates are employable'. Confederation of India Industry (CII) in their survey found that only 10 per cent of MBA graduates are employable and 17 per cent of the Engineering graduates are employable. 25 per cent of the candidates are used in the job market and 60 per cent of the population is only available for working and contributing towards GDP. But, out of the total pool, only 25 per cent is capable of being used by the market and demand-supply gap of 82-86 per cent in the core professions; IT industry alone would face the shortage of up to 3.5 million skilled workers for the requirement of job.

Aspiring Minds [9] in their research study found that 47 per cent of graduates are not employable in any sector, given their English language and cognitive skills. The need for improved focus on vocational training, specific targeted intervention in areas of computer and English skill are highlighted. Less than 25 per cent students are able to apply concepts to problem-solving. Our higher education system needs to lay greater stress on application of concepts and discourage habit learning. Employers should also start questioning their traditional ways of selecting and sourcing graduates and find new ways to reach employable youth. All India Council for Technical Education (AICTE) developed model curriculum for different programs under technical education after involving industry representatives in their curriculum development activity as part of skill initiatives under different sectors, which is improving the employability. The AICTE has identified 16 Sectors and 79 Specializations and also developed required curriculum for the different levels of skill in their respective specialization/sectors.

It is estimated that about 25 per cent of the total working population in the world will live in India by the end of 2010. Out of the total working population in India, a large workforce is waiting for the work opportunities. It is estimated that by 2025 , about 300 million educated youth will be waiting for jobs/ employment in the country. About 57 per cent of them will not be having requisite skills 
for employment. About 90 per cent of the school / college leavers will have bookish knowledge instead of vocational knowledge. Only 7 per cent of the youth, who are in the age group of 15-29 years, will receive vocational training.

But as per the recent NSSO data, in India, it is hardly covers five per cent of the population in age group of 19 to 24 years have learnt skills through the vocational education stream. Remaining 95 per cent of the school / college leavers will have bookish knowledge instead of vocational knowledge. Whereas about 90 to 95 per cent of the youth in other parts of world viz., Russia (60\%), China (55\%), Chile (40\%) and Korea (31\%) are learning a skill or competence or trade and taking the subjects relating to vocational skills training and all these countries have a trained and qualified people in the workforce. Further, more than 50 per cent of the employed youth are disadvantaged due to workplace skills.

It is very pathetic that the country is facing a dual challenge of paucity of highly trained workforce in one side and nonemployability of large sections of the conventionally educated youth, who possess little or no job skills, in another side. The country, however, has a big challenge ahead as it is estimated that only 4.69 per cent of the total workforce in India has undergone formal skill training courses as compared to 68 per cent in UK, 75 per cent in Germany, 52 per cent in USA, 80 per cent in Japan and 96 per cent in South Korea [10].

Of the total population (1.3 billion) in India, over half of the people are younger than 25 years old. Yet, only two per cent of its 500 Million workforces have some skills or training. The majority work in the informal sector $(90 \%)$, where there are less opportunities for education other than what workers 'pick up' on the job. This reality limits overall productivity, as well as upward mobility. With over 12 million young people joining the workforce each year, India has made vocational training a top priority; in 2012 , the Indian government set a target to train 500 million people by 2020 [11]. India has made Vocational Training a top priority to create 500 million certified and skilled technicians by the end of 2020 .

Recruitment companies say that many of the students, who are coming out with graduate degrees, do not have requisite employability skills to secure employment. It is estimated that by 2025, about 300 million educated youth will be waiting for jobs/ employment in the country. However, employers in India are facing a huge shortage of skilled manpower. Presently, there is a little connection between education and employability of students. Many students are not able to acquire the practical skills, uncertain about their future careers and do not see the relevance of their education for employment.

\section{Need for employability of students}

Employability skills allow you to communicate with co-workers, solve problems, understand your role within a team, make appropriate choices, and be responsible for your own career. Personal qualities, habits, and attitudes influence how you interact with others. Employers place great value for these skills because they are linked to how you manage relationship with co-workers and customers, your job performance, and your career success [8]. Employability skills are important because the labour market is intensely competitive, and employers are looking for people who are flexible, take the initiative and have the ability to undertake a variety of tasks in different environments. These skills prepare people for work-readiness, improve their employment prospects and help unemployed people to look for work.

Employability is used as a performance indicator relating to the employment rates of graduates. Employability, as a commodity, is seen as vital for economic growth of the country. It is mainly to meet the employer needs and they are in favour of the more generic skills which they have acquired. Indeed, some employers have placed less importance on graduates' actual degree discipline in favor of the more generic skills which they have acquired. Employers are demanding skills from graduates which are outside the subject area of study in Higher Education. Employers generally see a graduate's achievements related to the subject discipline as necessary but not sufficient for them to be recruited. Achievements outside the boundaries of the discipline extracurricular activities such as work experience, volunteering, and involvement in clubs and societies are seen as having equal importance in this context as the knowledge and experience acquired through academic study. Industry is looking for graduates who come equipped with the skills to begin their employment confidently and are work ready. It favors the practical and operational competence of the work environment [12].

Prospective students (and parents) carefully weigh up their future employment prospects when selecting the courses and universities. They consult university league tables and sources which publish graduate destination data and starting salaries. With the rise of tuition fees, students will look more carefully for a return on their investment. Support increased opportunities for student work experience, placements and internships. Explicitly articulate the relevant graduate employability skills in the learning outcomes for every subject.

\section{Pre-requisites for employability of students}

Employability depends on the knowledge, skills and attitude of the youth. The students have to apply the knowledge/skills to derive benefit and get the employment. The methods which provide the opportunities for application of knowledge or practice include: Case study, Projects, Workshops, Assignments and practical skills. 
Producing employable graduates' is a part of the process of education. It encompasses the full educational spectrum of values from imparting knowledge and understanding to develop the skills and attributes. Employability skills are not as narrowly prescribed and defined as in the past and generally, they are more 'service oriented', making information and social skills increasingly important.

Transferable Skills such as Writing Skills, IT Skills, Personal Development, Presentation Skills, Team Work, Research Skills, Multiple skills are required; To ensure the students of higher education to get connected to employment: they must aware of various employment opportunities, have high aspirations, skills necessary to manage their careers, appropriate work experience, the ability to make effective applications for employment.

\section{Challenges for the employability of students in Higher Education}

Many challenges are faced for the employability of higher education students in India. For many students, mastering employability skills can be a challenging and confronting process, requiring intensive teacher and school input and explicit teaching, role modeling and task planning [13]. The major challenges for developing employable traits among the students to secure the placements in the companies/establishments are relating to the managements, faculty members and also the students. They are briefly described hereunder:

When we ask the students why you are lagging behind on the employable counts/traits, many of them tell that, the college managements do not provide enough training in the subject/courses [14]. In most of the colleges, the managements are not providing required resources and infrastructure facilities to have the practical skills; they do not have proper control over the teachers and nonteachers; they do not have proper relations/ linkages with employers. Though the resources and infrastructure facilities made available by the institutional managements, consumption of those facilities depends on the students. They should be regular to the classes, disciplined and alert in all the activities of the institute. They should develop problem solving and analytical skills, learn the English which is globally accepted link language; improve personality, which is actually a framework and includes a variety of traits such as positive thinking, awareness, sense of humor, knowledge, wisdom and pleasing manners etc. The graduate students are unable to develop self-confidence/ high aspirations; students are not aware of suitable job opportunities; they are not thorough with the course curriculum and career related experience; their involvement in extra-curricular activities is poor; they are not making good career decisions; they do not have career development/management skills; they are not aware of selection procedure.

The job opportunities for students are not many. Too many student graduates are competing for the same job. White-collar jobs are in demand. There is a demand for the new skills and rapid growth. Most of our students, who are intended to enter into the world of work, lack knowledge in their subjects, week in soft skills, confidence levels, majority of them are not serious about their future and have improper dressing and improper body language. Most of the students learn it on their own and they do not receive proper guidance in the content areas such as personality, confidence building, soft skills etc. Further, the colleges hardly conduct seminars, group discussions and mock interviews, which are required to improve the communication skills and confidence levels of students.

The faculty members are expected to provide required training to secure employment besides teaching of subjects. But, all the teachers are not providing enough training in the subject/courses to meet the requirements of employers; they are poor in conducting of seminars, group discussions \& mock interviews for students; they are not arranging proper placement services to assist students; their relations with employers are insignificant; many are not arranging coaching classes to the students to train in the employability skills besides regular subjects; unable to develop needed skills such as problem solving, analytical skills and English language and other traits such as positive thinking, sense of humor, knowledge, wisdom, pleasing manners etc.

\section{Strategies for enhancing the employability of students}

The Bond University has developed eight strategies for the graduate employability, which are relevant and are important means to deliver superior graduate outcomes with a focus on globally relevant careers [15]. These eight strategies are described hereunder:

\section{Arrange To Provide the Students with Work Experience, Placements and Internships}

This is one of the strategies emerged from the education research, including the recent Bond-led National project, is work experience, placements and internships. Teacher networks provide the top means of identifying and securing these opportunities for students. Use our discipline/ industry connections to build partnership opportunities for students. Stay in close contact with the Career Development Centre and make introductions. Suggest opportunities to students and recommend them to industry contacts. Maintain a flexible, personalised curriculum and program offering, such that students, who optimize their education experience through work experience, placement and internship opportunities, are not disadvantaged by missing required subjects or sequences. Take a cocurricular approach, whereby we explicitly direct the students to draw-upon their work experiences to prepare assessment, graduate portfolios and other core learning experiences.

\section{Explicitly Articulate the Relevant Graduate Employability Skills in the Learning Outcomes for Every Subject}


While transacting each subject, the teachers deeply consider how this subject aligns with graduate employability and discuss with students at the beginning and throughout every semester. Ensure that at least one of the learning outcomes for every subject explicitly links to 'graduate employability' helping the students to put the puzzle pieces together for optimised graduate outcomes.

\section{Design Authentic Assessment Activities, Aligned With Industry Practices, Standards and Approaches}

In designing assessment, ask yourself whether the outcome, process and mode are equivalent to those currently being used in graduate destinations. For example, if most of your assessment items are paper-based multiple-choice exams, it is important to ask yourself whether employees in industries where your graduates are commonly employed typically work off-line and are required to recall fact-based information on a regular basis. If your assessment requires students to write a series of long, referenced research essays, it is important to ask whether the emphasis on this skill is adequately developing their possible industry-based skills such as creating press releases and short social media posts. While essays can be a necessary academic skill to prepare some students for future post-graduate work, is assessment adequately balanced such that multiple types of graduate outcomes are supported? Know the typical, common and/or range of destinations of your graduates. Analyze what types of work these graduates do and align your assessment accordingly.

\section{Know Your Disciplines' Career Options and Outcomes and Be Explicit About Career Pathways}

When choosing a degree pathway, students and parents want to know about career outcomes, graduate pathways and success stories. It is important to stay in contact with graduates in order to inform yourself and your future students. However, this information is not only relevant to prospective or future students on a marketing basis, but to your current students. It is important to align lessons and assessment with industry trends and practices. Employment is constantly changing and new opportunities emerging. In order to adjust curriculum and learning experiences accordingly, it is vital to stay connected to industry. Remember to regularly share this information with students and engage them in reflective conversation about graduate employability.

\section{Make the Learning Experience about Knowledge, Skills and Attributes}

It is appropriate that teachers read, recited or lectured long passages. They had the information and the students did not. The efficient means of passing on that knowledge was through verbal report to large groups of students. Now the students have access to most if not all of the necessary information through books, the web, video recordings and countless other sources. The teacher's role has shifted to one of helping students filter, evaluate and apply the information. Employers are vocal about the destructive nature of teachers who have continued teaching through long lectures followed by recall exams. Employers state that graduates are arriving with university HDs but limited technical skill and soft skill such as that demonstrated by professionally taking and adjusting to feedback, working in a legitimate team and appropriately interacting socially. It is important that teachers know what graduates will need to be able to do and then design learning experiences such that these skills are developed through the program of studies.

\section{Invite Employers to Engage}

Throughout the Bond-led national research project on graduate employability, employers said that they want to engage with universities in order to develop quality employees. There are numerous ways in which to involve employers viz., i) Invite employers as guest speakers or panelists; ii) Review your curriculum and assessment with employers and ask for their feedback on whether, when and how they use this knowledge and these skills in their careers. Explicitly present this information to students when introducing a new module and/or new assessment; iii) Ask employers to grade/rank/evaluate/provide feedback on submitted assessment. For example, if you are assessing a tender proposal, ask a panel of employers to share which bid they would select and why; and iv) Develop case studies with employers and use these as learning materials with your students.

\section{Invite Ex-Graduates to Engage}

Likewise, invite ex-graduates to come on-campus and/or online through iLearn and share their experiences with your current students. In addition to the engagement ideas as shared with respect to employers, consider also inviting a panel of graduates to address and answer questions from your students. Here are some questions that can be posed to ex-graduates: i) what are you doing now? ii) What is your advice for current students? About their studies? About their approach to seeking employment? About what they should be doing as students to ensure they are employable? iii) What do you wish you would have known as a student that you know now as a graduate? iv) How do you see your industry changing/evolving? What can students do to prepare? v) What knowledge, skills and attributes are key to your career?

\section{Explicitly Teach Students How To Be Employable}

The teachers may have conversations with students about employability at the beginning, middle and end of the semester. The following are the specific employability recommendations that emerged for students through the Bond-led national project: a) Start early, such as in your first semester; b) Participate in work experience, placements and internships; c) Join in extra-curricular and cocurricular activities (e.g. student societies, clubs and competitive sport); and d) Get to know your professors and your career development centre personnel. Discuss each of these key points with your students.

Besides the above, the following strategies are also considered for employability of students: 
- There are lots of illusions in our society. They encourage the youth with negative way. They told them that this education is just for knowledge not for employment. Instead of this saying, parents should encourage positively that this education will make you engineer, doctor, teacher if you work hard. Hard work is the key of success.

- Instead of finding any job, it is good; you encourage youth to do some self-business. They can start it with 2-5 friends' partnership. Partnership will run on the basis of honesty and truth. They can make/create/innovate anything and then sell it in the market. In beginning, they might face losses, but should be comforted not to fear from these losses. Only after tolerating the losses, you will get success in the business.

- Teachers and parents should teach self employment to the youth. They have to tell that self employment is best. They have to teach any skill which should be valuable for society. You can teach the work of carpentry. After getting this skill, you never live free because there is big use of furniture products and its producer is carpenter. Like this, there are lots of vocational and self employment skills which youth can learn.

- Every student in China learns to make machine, blade, tools, eating products and other technical skills. After getting, they get good employment. But in India, they learn MA in Hindi, MA in English, and MA in political science. I am not against these MA, if your children are interested in it. It is good but with this, we have to learn some technical skills. At that time, we will give more opportunity to youth for getting employment.

- $\quad$ Shy is the main problem in youth. No work is big or small. If you have higher education and are unemployed start to work from small. You can do marketing from your cycle. With this, your marketing skill will be developed. After this, you can get more chance in big company. So never shy.

\section{CONCLUSION}

The paper presenter has discussed about the concept of employability and the status of employability of students in India. Need for the employability of students in relation to increase the GDP and economic development of the country. Some of the prerequisites for employability of students are also briefly presented. Various challenges faced for the employability of students from the point of view of students, teachers and the managements are also examined. Further, the strategies to be followed for the employability of students with particular reference to higher educational institutions are discussed.

\section{REFERENCES}

1. Yorke, M. (2006). Employability in Higher Education: what it is - what it is not, Higher Education Academy/ESECT Learning \& Employability Series? Retrieved from https://www.heacademy.ac.uk/node/3263.

2. Hillage, J. (1998). Employability: Developing a Framework for Policy Analysis. http://books.google.com/books/about/Employability.html: Research Report RR85, Department for Education and Employment. ISBN 9780855228897.

3. Knight, P., \& Yorke, M. (2004). Learning, curriculum and employability in higher education. London: Routledg eFalmer.

4. Hinchliffe, G.W., \& Jolly, A. (2011). Graduate identity and employability. British Educational Research Journal, 37(4), 563-584.

5. Holmes, L. (2013). Competing perspectives on graduate employability: Possession, position or process? Studies in Higher Education, 38(4), 538- 554.

6. Yorke, M. (2006). Employability in higher education: What it is - what it is not. Retrieved from https://www.heacademy.ac.uk/node/3263

7. Yorke, M., \& Knight, P. (2006). Curricula for economic and social gain. Higher Education, 51(4), 565-588.

8. Subramanian, K. R. (2017). Higher Education and Employability Skills. International Journal of Combined Research \& Development (IJCRD), 6(1).

9. ASSHOCHAM Employability Survey. (2014). Adapted from Business Standard Beta at (1. Aspiring Minds' MBA, National Employability Report (2014), adapted from (http://www.aspiringminds.in/whitepapers.html).

10. UNESCO. (2012). Youth and skills. Putting education to work. Education for All Global Monitoring Report 2012. Paris.

11. Acumen. (2014). Why India's Economic Growth Depends on Vocational Training, October 30, 2014 by Acumen in Acumen Blog, On the Ground, Our World.

12. Light, G., Calkins, S., \& Cox, R. (2009). Learning and teaching in higher education: The reflective professional. Sage.

13. Reddy, M. C. R. (2014). Career Guidance and Counseling services for employability of youth paper presented in the National Seminar on 'Career Guidance and Employability of Skills for the Youth' organized by the Dept of Adult, Continuing Education, S.V.University, Tirupati held on 7-8 March, 2014.

14. Reddy, M. C. R. (2014). Student Placements: Challenges and Opportunities, Paper presented in the Seminar on Student Placements - problems and Issues in the Changing Environment, in the Dept. of Adult continuing Education, Extension and Field Outreach, Acharya Nagarjuna University, Guntur held on 22-23 Jan., 2009.

15. Kinash, S. (2015). 8 ways to enhance your students' graduate employability. Teaching the Bond Way, (2), 1-14. 